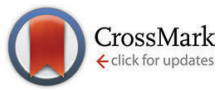

Cite this: New J. Chem., 2017 41, 1566

Received 31st May 2016 Accepted 5th January 2017

DOI: $10.1039 / c 6 n j 01703 g$

www.rsc.org/njc

\title{
Synthesis and evaluation of benzothiazole-triazole and benzothiadiazole-triazole scaffolds as potential molecular probes for amyloid- $\beta$ aggregation $\dagger$
}

\author{
Christine Dyrager, $\ddagger^{\star a b}$ Rafael Pinto Vieira, ${ }^{\text {acd }}$ Sofie Nyström, ${ }^{\mathrm{b}}$ K. Peter R. Nilsson ${ }^{\mathrm{b}}$ \\ and Tim Storr ${ }^{\mathrm{a}}$
}

\begin{abstract}
Small-molecule ligands that bind to misfolded protein aggregates are essential tools for the study and detection of pathological hallmarks in neurodegenerative disorders, such as Alzheimer's disease (AD). In the present study, three compounds (one benzothiazole-triazole, L1, and two benzothiadiazoletriazoles, L2 and L3) were synthesized via a modular approach (azide-alkyne cycloaddition) and evaluated as potential ligands for amyloid- $\beta$ (A $\beta$ ) aggregates. The binding to amyloid-like fibrils, generated from recombinant $A \beta_{1-42}$, were studied and the binding specificity to amyloid deposits was evaluated in brain sections from transgenic mice with $A D$ pathology. All three derivatives showed significant reduced emission in the presence of recombinant $A \beta_{1-42}$ amyloid fibrils. In addition, the observed binding to $A \beta$ deposits in tissue sections suggests that the benzothiazole-triazole and benzothiadiazole-triazole structures are promising molecular scaffolds that can be modified for binding to specific protein aggregates.
\end{abstract}

\section{Introduction}

One of the common pathological hallmarks of neurodegenerative disorders, such as Alzheimer's disease (AD), Parkinson's and Huntington's disease, and the infectious prion diseases are the formation of misfolded protein aggregates in the brain. ${ }^{1-4}$ Thus, development of new molecular probes for the detection of protein aggregates is of great importance in order to understand the pathology of these diseases. ${ }^{5-8}$ For example, probes that can be prepared via a modular synthetic approach to generate structures with diversity are desirable. To date, the most commonly used ligands for studying protein aggregation are thioflavin $\mathrm{T}$ (ThT) and Congo red (CR) (Fig. 1). ThT, which is a benzothiazole dye, is used due to its impressive increase in fluorescence intensity ( $c a$. 1000-fold) in the presence of protein fibrils, a phenomenon that is due to conformational rigidity

\footnotetext{
${ }^{a}$ Department of Chemistry, Simon Fraser University, Burnaby, British Columbia V5A 1S6, Canada

${ }^{b}$ Department of Physics, Chemistry and Biology, Linköping University, 58183 Linköping, Sweden

${ }^{c}$ Departamento de Bioquímica e Imunologia, Instituto de Ciências Biológicas, Universidade Federal de Minas Gerais, 31270-901 Belo Horizonte, MG, Brazil

${ }^{d}$ CAPES Foundation, Ministry of Education of Brazil, 70040-020 Brasilia, DF, Brazil $\dagger$ Electronic supplementary information (ESI) available. See DOI: 10.1039/c6nj01703g ‡ Division of Organic Chemistry, Department of Physics, Chemistry and Biology, Linköping University, SE-58183, Linköping, Sweden. E-mail: christine.dyrager@ liu.se; Tel: +46 13281311 .
}

upon binding..$^{9-11}$ However, the practical use of ThT has been debated since it has limitations; e.g. it is not able to distinguish between prefibrillar and fibrillar aggregates and some protein aggregates do not affect its fluorescence, leading to false negatives. ${ }^{12,13}$ In addition, CR, (an aromatic azo dye) is commonly used for staining protein aggregates in histology samples. ${ }^{14-16}$ However, CR staining can give misleading results due to the thickness of the sample and the orientation of the amyloid deposits. ${ }^{13}$ Hence, CR staining usually requires experience and sample control in order to generate reliable results. ${ }^{17}$ Although both ThT and CR are useful and well-established dyes for amyloid detection in tissue there is a need for alternative ligands, e.g. compounds that could be generated via a modular approach, in order to study different protein aggregates and their morphologies. Moreover, the use of nuclear imaging techniques, such as positron emission tomography (PET) and single photon emission computed tomography (SPECT) for the in vivo detection of protein aggregates (such as $\mathrm{A} \beta$ aggregates in $\mathrm{AD}$ ) has increased interest in the development of radiolabelled binding ligands. ${ }^{18}$ For example, Pittsburgh compound B, $\left[{ }^{11} \mathrm{C}\right] \mathrm{PIB}$, and Amyvid ${ }^{\mathrm{TM}}$ (florbetapir) (Fig. 1) are widely used in vivo as indicators for A $\beta$-deposits in brain tissue. ${ }^{19-21}$

In our search for small molecular scaffolds that bind to protein aggregates, we are particularly interested in synthetic pathways that involve a modular approach (e.g. click chemistry) that could generate diverse derivatives with specific binding properties. Initially for this study, we investigated if the combination of a 


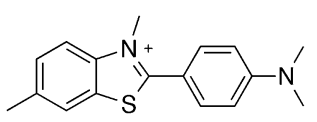

Thioflavin T<smiles></smiles>

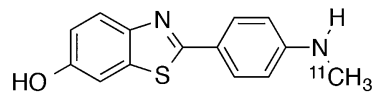

Pittsburgh Compound B

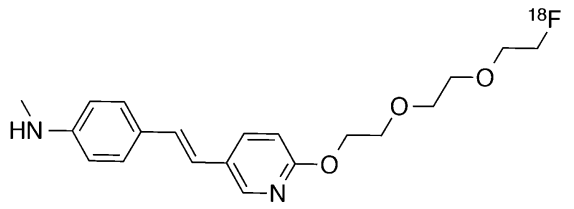

Amyvid ${ }^{\mathrm{TM}}$

Fig. 1 Chemical structures of known amyloid- $\beta$ ligands; thioflavin T (ThT), Congo red (CR), Pittsburgh compound B $\left(\left[{ }^{11} \mathrm{C}\right] \mathrm{PIB}\right)$ and $\mathrm{Amyvid} \mathrm{d}^{\mathrm{TM}}$ (florbetapir).<smiles>CCCn1cc(-c2nc3ccc(OC)cc3s2)nn1</smiles><smiles>OCCCn1cc(-c2ccc(-c3cn(CCCO)nn3)c3nsnc23)nn1</smiles>

L3

Fig. 2 Chemical structures of the benzothiazole-triazole (L1) and the benzothiadiazole-triazole derivatives ( $\mathbf{L} \mathbf{2}$ and $\mathbf{L} \mathbf{3}$ ).

1,2,3-triazole moiety and two well-known chromophores, benzothiazole and benzothiadiazole, could afford ligands that exhibit amyloid binding properties in histology samples. Our approach was to use a small azide (3-azidopropan-1-ol) when forming the triazole ring in order to generate model compounds that could be used as a proof-of-concept for amyloid detection. ${ }^{22,23}$ Hence, in this paper we report the synthesis and evaluation of three new compounds (one benzothiazole-triazole, L1, and two benzothiadiazole-triazoles, L2 and L3, Fig. 2) as potential ligand scaffolds for amyloid- $\beta$ aggregates in mouse brain sections.

\section{Results and discussion}

\subsection{Synthesis}

The target compounds (L1-L3) were synthesized as presented in Schemes 1 and 2. The benzothiazole-triazole derivative (L1, Scheme 1) was prepared by using commercially available 2-amino-6-methoxy-benzothiazole (1) as starting material. First, the amino functionality in the 2-position of $\mathbf{1}$ was replaced with iodine via diazotization-Sandmeyer iodination using $\mathrm{KI}, \mathrm{NaNO}_{2}$ and $p$-toluenesulfonic acid monohydrate in $\mathrm{H}_{2} \mathrm{O}$ /acetonitrile to afford compound $2 .^{24}$ Subsequently, TMS-acetylene was introduced in the 2-position of the iodinated compound (2) by using a palladium-mediated Sonogashira coupling under inert conditions with ethynyltrimethylsilane, $\mathrm{PdCl}_{2}\left(\mathrm{PPh}_{3}\right)_{2}$, and

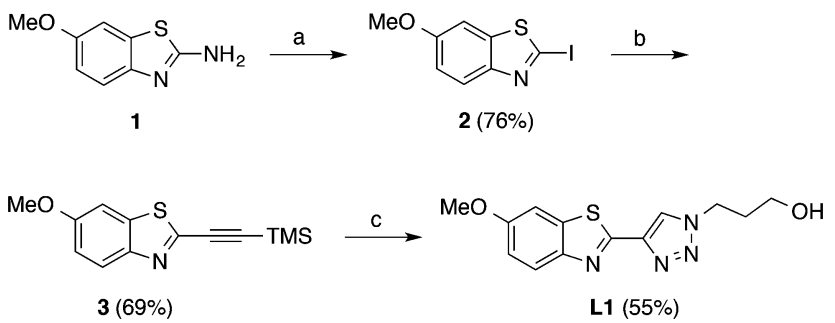

Scheme 1 Synthesis of the benzothiazole-triazole derivative, L1. Reagents and conditions: (a) $\mathrm{KI}, \mathrm{NaNO}_{2}, p$-toluenesulfonic acid monohydrate, $\mathrm{H}_{2} \mathrm{O}$, acetonitrile, $0{ }^{\circ} \mathrm{C}$ to $\mathrm{rt}$, overnight. (b) Ethynyltrimethylsilane, $\mathrm{PdCl}_{2}\left(\mathrm{PPh}_{3}\right)_{2}$, Cul, dichloromethane, reflux, 3 h. (c) TBAF (1 M in THF), 3-azidopropan-1-ol, $\mathrm{CuSO}_{4} \cdot \mathrm{H}_{2} \mathrm{O}$, L-sodium ascorbate, $\mathrm{H}_{2} \mathrm{O}, \mathrm{THF}, \mathrm{rt}, 3$ days.

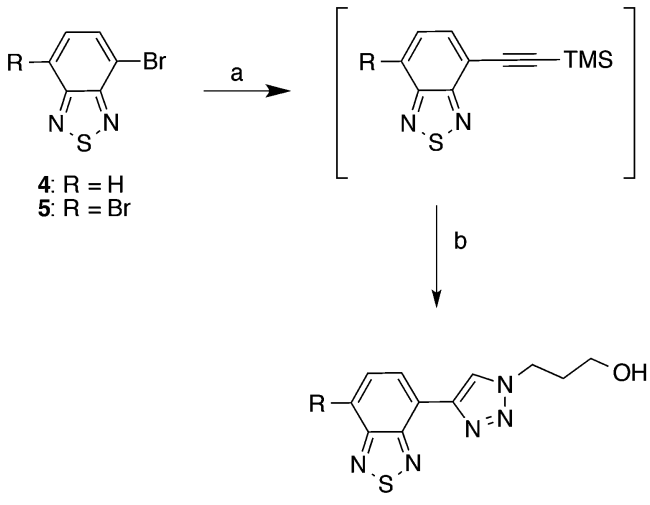

L2: $\mathrm{R}=\mathrm{H}(30 \%)$

L3: $\mathrm{R}=3-(1 H-1,2,3-$ triazol-1-yl)propan-1-ol (69\%)

Scheme 2 Synthesis of the benzothiadiazole-triazole derivatives, L2 and L3. Reagents and conditions: (a) ethynyltrimethylsilane, $\mathrm{PdCl}_{2}\left(\mathrm{PPh}_{3}\right)_{2}, \mathrm{PPh}_{3}$, Cul, NEt 3 , reflux, 4-18 h; (b) TBAF (1 $\mathrm{M}$ in THF), 3-azidopropan-1-ol, $\mathrm{CuSO}_{4} \cdot \mathrm{H}_{2} \mathrm{O}$, L-sodium ascorbate, $\mathrm{H}_{2} \mathrm{O}, \mathrm{THF}, \mathrm{rt}, 3$ days.

CuI in dichloromethane to give compound 3. Finally, deprotection of the TMS-group and the subsequent azide-alkyne Huisgen cycloaddition reaction (click chemistry) was performed simultaneously by mixing compound 3 with TBAF ( $1 \mathrm{M}$ in THF), 3-azidopropan-1-ol, $\mathrm{CuSO}_{4} \cdot \mathrm{H}_{2} \mathrm{O}$ and L-sodium ascorbate in $\mathrm{H}_{2} \mathrm{O} / \mathrm{THF}$ to give compound $\mathbf{L 1}$ in $55 \%$ yield. ${ }^{25,26}$ 
The benzothiadiazole-triazole derivatives (L2 and L3) (Scheme 2) were synthesized using the same procedure as above. However, the syntheses were regulated using different equivalents of the reagents in order to generate the mono- or disubstituted products. First, the starting materials, 4-bromo-2,1,3-benzothiadiazole (4) and 4,7-dibromo-2,1,3-benzothiadiazole (5), were synthesized using previous reported protocols (ESI, $\dagger$ Scheme S1). ${ }^{27-29}$ Subsequently, TMS-acetylene was introduced by a palladium-mediated Sonogashira reaction in the presence of ethynyltrimethylsilane, $\operatorname{PdCl}_{2}\left(\mathrm{PPh}_{3}\right)_{2}$, $\mathrm{PPh}_{3}$ and CuI, in triethylamine. Notably, the crude products were immediately carried forward in the next reaction step

Table 1 Spectroscopic data for compounds L1-L3 measured in 5\% DMSO in phosphate buffered saline (PBS, $10 \mathrm{mM}$ phosphate, $140 \mathrm{mM}$ $\mathrm{NaCl}, 2.7 \mathrm{mM} \mathrm{KCl}, \mathrm{pH} 7.4$ )

\begin{tabular}{llllcl}
\hline Compound & $\begin{array}{l}\lambda_{\text {abs }} \\
(\mathrm{nm})\end{array}$ & $\begin{array}{l}\lambda_{\text {em }} \\
(\mathrm{nm})\end{array}$ & $\begin{array}{l}\text { Stoke's shift } \\
(\mathrm{nm})\end{array}$ & $\varepsilon\left[\mathrm{M}^{-1} \mathrm{~cm}^{-1}\right]$ & $\phi_{\mathrm{F}}{ }^{a}$ \\
\hline L1 & 313 & 391 & 78 & 9000 & 0.67 \\
L2 & 353 & 494 & 141 & 11000 & 0.24 \\
L3 & 387 & 531 & 144 & 8000 & 0.31
\end{tabular}

${ }^{a}$ Determined relative to quinine sulfate in aqueous $\mathrm{H}_{2} \mathrm{SO}_{4}(0.1 \mathrm{M})$. due to limited compound stability. Next, deprotection of the TMS-group and subsequent click reaction was performed simultaneously by mixing the crude product from the previous reaction step with TBAF ( $1 \mathrm{M}$ in THF), 3-azidopropan-1-ol, $\mathrm{CuSO}_{4} \cdot \mathrm{H}_{2} \mathrm{O}$ and L-sodium ascorbate in $\mathrm{H}_{2} \mathrm{O}$ /THF, affording $\mathbf{L 2}$ and $\mathbf{L} 3$ in 30\% and 69\% yield, respectively (over three steps). ${ }^{30}$

\subsection{Photophysical measurements}

2.2.1. Photophysical characterization of compound L1-L3. Absorption and emission profiles for L1-L3 were determined in $5 \%$ DMSO in phosphate buffered saline (PBS, $10 \mathrm{mM}$ phosphate, $140 \mathrm{mM} \mathrm{NaCl}, 2.7 \mathrm{mM} \mathrm{KCl}, \mathrm{pH}$ 7.4) (Table 1) (for spectra see ESI, $\dagger$ Fig. S1). The molar extinction coefficients for the ligands were similar, ranging from $8000-11000\left[\mathrm{M}^{-1} \mathrm{~cm}^{-1}\right]$. The benzothiazoletriazole derivative (L1) showed a high-energy absorption band at $313 \mathrm{~nm}$ and emission maxima at $391 \mathrm{~nm}$, whereas the absorption and emission maxima for the benzothiadiazole-triazole derivatives (L2-L3) were more redshifted (L2: $\lambda_{\mathrm{abs}}=353 \mathrm{~nm}, \lambda_{\mathrm{em}}=494 \mathrm{~nm}$; L3: $\left.\lambda_{\mathrm{abs}}=387 \mathrm{~nm}, \lambda_{\mathrm{em}}=531 \mathrm{~nm}\right)$. These results were expected since the benzothiadiazole fragment is well known for its interesting photophysical properties, such as the strong electron-withdrawing capacity that facilitates intramolecular charge transfer (ICT), large a)

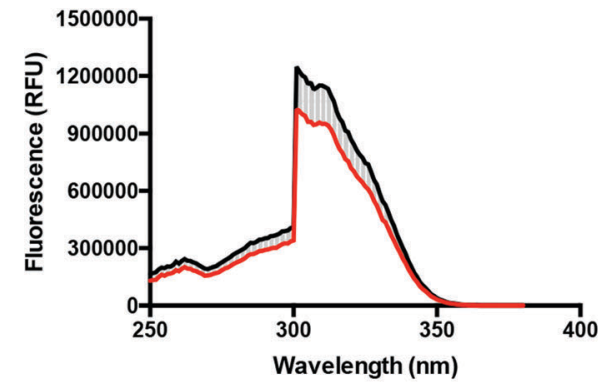

b)

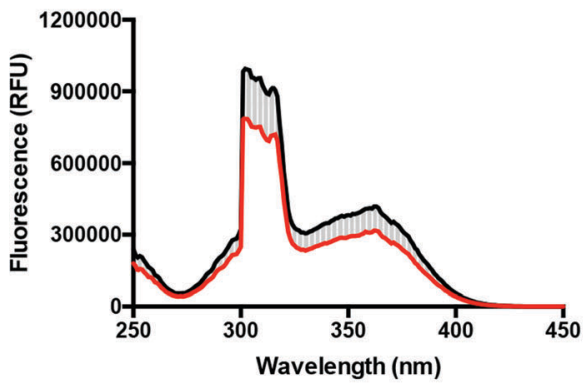

c)

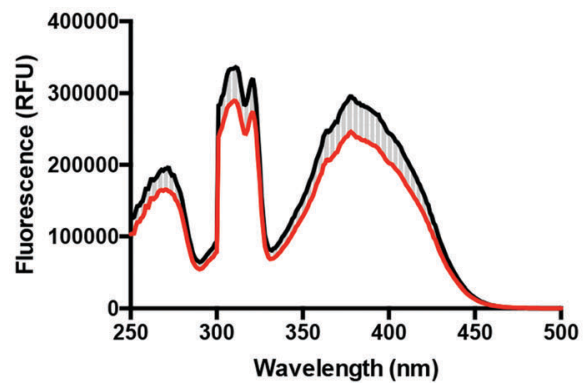

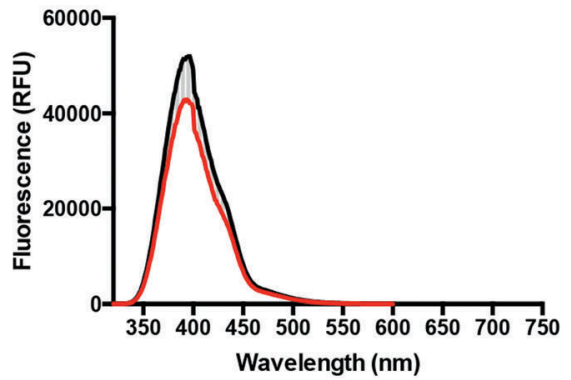
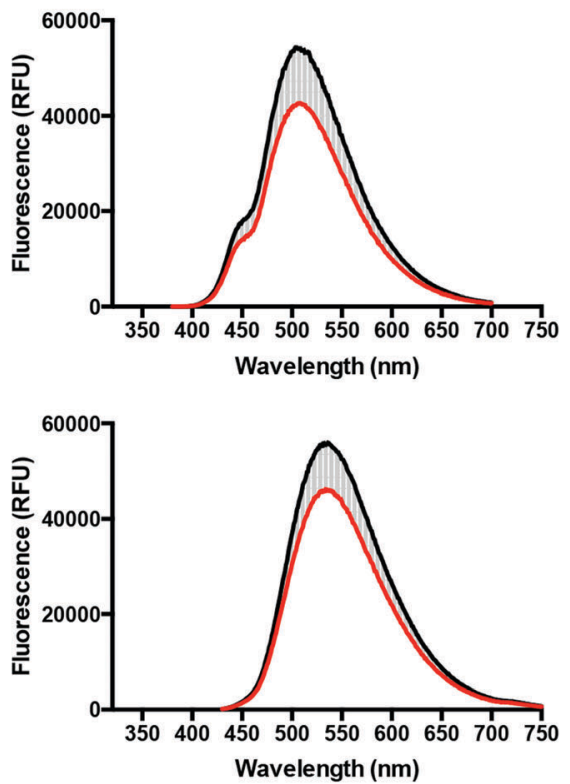

Fig. 3 Excitation (left) and emission (right) spectra of L1 (a), L2 (b), and L3 (c) in the presence (red line) or absence (black line) of recombinant A $\beta_{1-42}$ fibrils in $5 \%$ DMSO in phosphate buffered saline (PBS, $10 \mathrm{mM}$ phosphate, $140 \mathrm{mM} \mathrm{NaCl}, 2.7 \mathrm{mM} \mathrm{KCl}, \mathrm{pH} 7.4$ ). The reduced emission intensities are represented by the light grey striped area. The measurements were performed in a $5: 1$ ratio, ligand to fibrils, using the concentrations $50 \mu \mathrm{M}$ and $10 \mu \mathrm{M}$, respectively. 
Stoke's shifts, high signal-to-noise ratio in cells and red-shifted optical profiles. ${ }^{31}$ In particular, the latter is beneficial in protein binding studies and tissue staining experiments due to the use of lower energies for excitation, and resulting lower autofluorescence signals and reduced light scattering. Further, quantum yield measurements for the ligands (in 5\% DMSO in PBS buffer, $\mathrm{pH}$ 7.4) afforded moderate to high $\phi_{\mathrm{F}}$ values $(0.67,0.24$ and 0.31 for L1, L2 and L3, respectively) (Table 1). The $\mathrm{pH}$ dependence ( $\mathrm{pH} 2-12)$ of the fluorophores was also investigated, and the fluorescent intensities and emission maxima was unchanged in a wide range $(\mathrm{pH} 4-12$, see ESI, $\dagger$ Fig. S2). However, a reduced intensity was observed at $\mathrm{pH} 2$, likely due to protonation of the benzothia(dia)zole fragments. ${ }^{32}$ Despite the blue-shifted absorption and emission maxima for $\mathbf{L 1}$ we further investigate all three compounds (L1-L3) for their amyloid binding potential in solution and in $\mathrm{AD}$ brain tissue.

2.2.2. Photophysical characterization of the benzothiazoletriazole (L1) and benzothiadiazole-triazole derivatives (L2 and L3) towards recombinant $A \beta_{1-42}$ amyloid fibrils. In order to evaluate potential interactions with protein aggregates, excitation and emission spectra of the ligands (L1-L3) were recorded in the absence and the presence of amyloid-like fibrils, generated from recombinant $A \beta_{1-42}$ (Fig. 3). Initially, the emission spectra of $\mathbf{L 1}-\mathbf{L} 3$ in the presence of $10 \mu \mathrm{M} A \beta$-fibrils were collected using different concentrations of the ligands $(0.3,0.6,0.9,1.2,10$ and
$100 \mu \mathrm{M})$ (spectra not shown). However, a ligand concentration of $50 \mu \mathrm{M}$ was chosen for further analysis due to the optimal linearresponse between absorbance and integrated fluorescence intensity (ESI, $\uparrow$ Fig. S4). Interestingly, all three ligands show reduced fluorescence (intensity area), approx. 20\% (reduced excitation intensity: $\mathbf{L 1}=16 \%, \mathbf{L 2}=17 \%, \mathbf{L 3}=23 \%$; reduced emission intensity: $\mathbf{L 1}=17 \%, \mathbf{L 2}=21 \%, \mathbf{L} 3=17 \%$, when mixed with the fibrils in solution, quite the contrary to ThT, which shows an increase in emission intensity. Interestingly, the absorbance-integrated luminescence intensity curves for L1-L3 (ESI, $\dagger$ Fig. S4) show fluorescence quenching $(\mathbf{L} 3>\mathbf{L 1}>\mathbf{L 2})$ at high concentrations $(>100 \mu \mathbf{M})$ in the absence of aggregates, and we thus hypothesize that the decreased intensity in the fibril experiment could originate from proximity-induced self-quenching of the ligands upon interaction with the A $\beta$-fibrils. ${ }^{33-37}$ Even if the ligands have a different photophysical behavior in comparison to ThT, the approx. $20 \%$ reduced intensity provides a useful and pronounced evidence of ligand-fibril interaction without approaching the limit of detection.

\subsection{Staining of $A \beta$-plaques in brain tissue sections from transgenic mice}

$\mathrm{A} \beta$ plaques in the APP/PS1 mouse model of AD pathology ${ }^{38}$ were stained simultaneously with the ligands L1, L2 or L3 and with an anti-A $\beta$ antibody (6E10) and then imaged via channels selective for a)

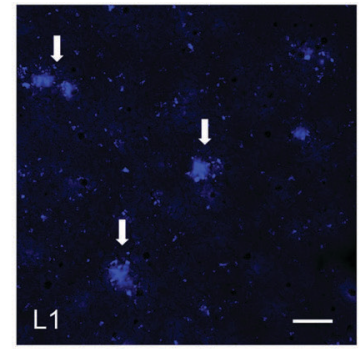

b)

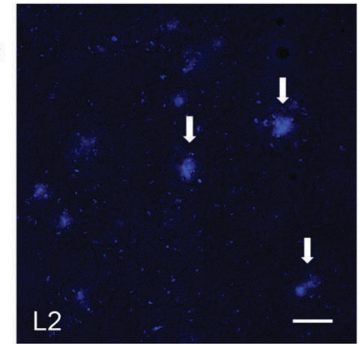

c)

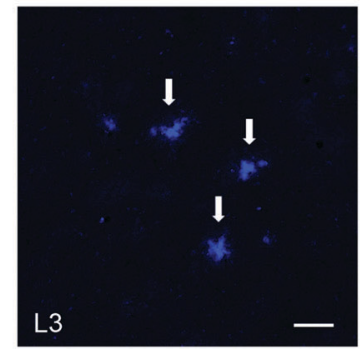

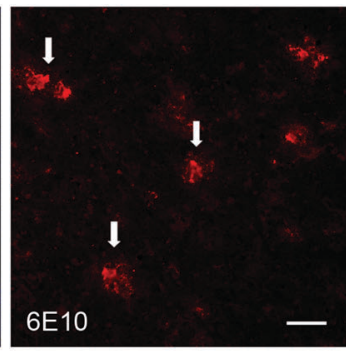
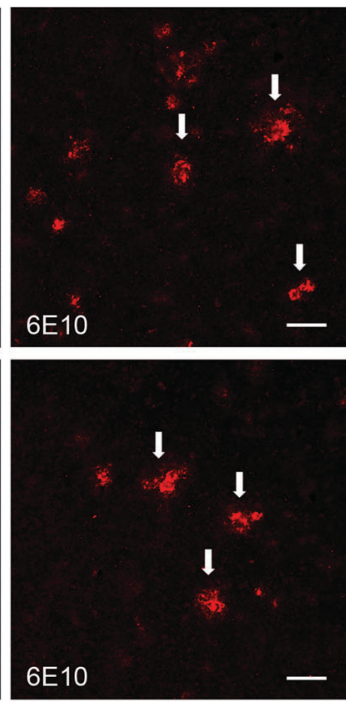
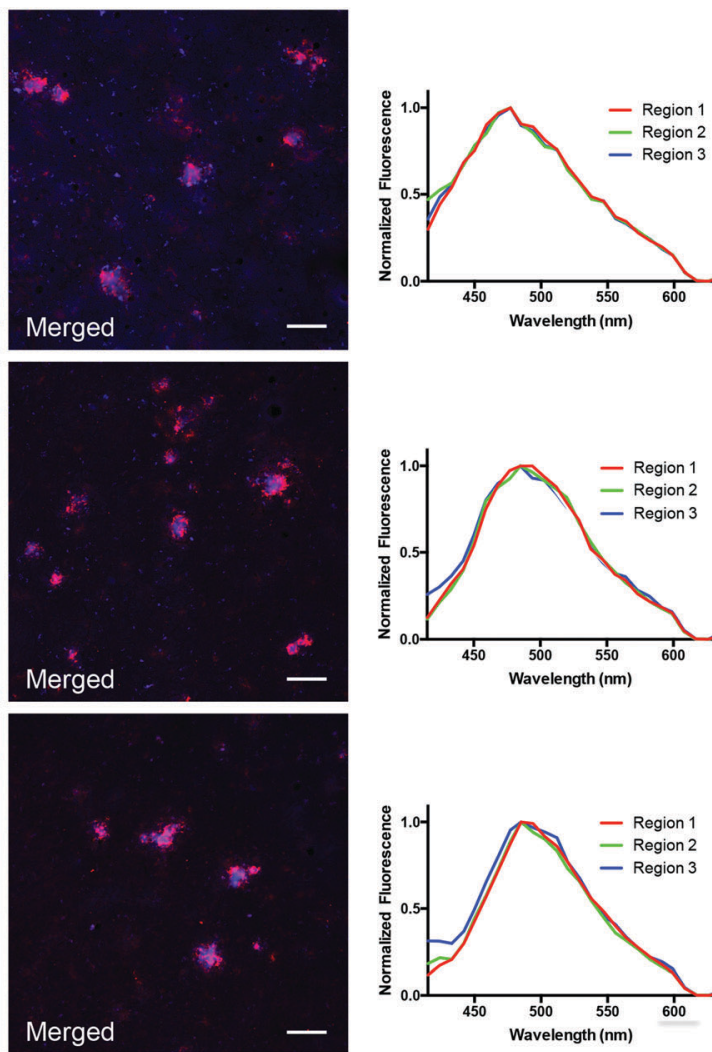
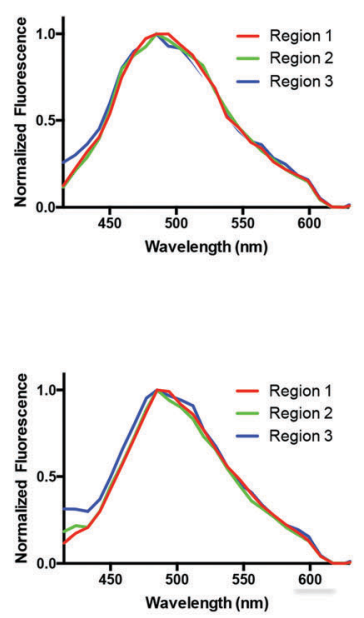

Fig. 4 Fluorescence microscopy images of A $\beta$ deposits in brain sections from APP/PS1 mice stained with L1 (a) L2 (b) and L3 (c), and with an anti-A $\beta$ antibody (6E10). White arrows point towards the localization of three representative amyloid deposits in each image stained with ligand (panels to the left) or anti-A $\beta$ antibody (6E10) (panels in the middle). Panels to the right show both channels in order to clarify the co-localization between ligand (seen in blue) and the anti-A $\beta$ antibody (seen in red). The emission spectra (excitation at $405 \mathrm{~nm}$ ) of each ligand binding to the core of three different $A \beta$ plaques (labeled as region 1, 2 and 3) are shown to the far right. The scale bar in the lower right corner of each image represents $50 \mu \mathrm{m}$. 
one or the other stain (excitation at 405 and $680 \mathrm{~nm}$, respectively). The resulting images (Fig. 4) clearly demonstrate that all three ligands bind to $\mathrm{A} \beta$ plaques with specificity and accuracy with L3 affording the best signal to background contrast. All three ligands display preferential binding to the plaque cores analogous to what has been described previously for this mouse model when stained with ThT or CN-PIB, which is expected due to the overall similarity in chemical structure between the ligands (L1-L3) and the well-established counterparts. ${ }^{39}$ This in turn holds promise that these new ligands may play a significant role as scaffolds for further development of amyloid-binding ligands with specific designs for various purposes using click chemistry for rapid multipurpose modification to improve binding affinities and pharmacokinetics.

Notably, as depicted in Fig. 4a (to the far right), the emission profile for $\mathbf{L 1}$ is more redshifted $\left(\lambda_{\mathrm{em}} \sim 470 \mathrm{~nm}\right)$ in the fluorescent microscopy experiment (using histology samples) in comparison with the photophysical characterization measurements in 5\% DMSO in PBS buffer $\left(\lambda_{\mathrm{em}}=394 \mathrm{~nm}\right.$ ) (Table 1). We hypothesized that this result was not an optical effect that originates from binding to the $\mathrm{A} \beta$ deposits in brain tissue, and instead a result from using a longer excitation wavelength (i.e. $405 \mathrm{~nm}$ instead of $310 \mathrm{~nm}$ ) in the tissue experiment. Furthermore, the redshift was verified by measuring the emission spectra of $\mathbf{L 1}$ in $5 \%$ DMSO in phosphate buffered saline (PBS, $10 \mathrm{mM}$ phosphate, $140 \mathrm{mM} \mathrm{NaCl}, 2.7 \mathrm{mM} \mathrm{KCl}, \mathrm{pH} 7.4)$ when exciting at $405 \mathrm{~nm}$, which afforded an emission maxima at $472 \mathrm{~nm}$ (see ESI, $\dagger$ Fig. S5a). However, even though it is possible to excite L1 at a lower energy and generate a red-shifted emission profile, we clearly observed that the benzothiadiazole derivatives $\mathbf{L} 2$ and $\mathbf{L} 3$ are much brighter, affording higher signal-to-noise ratios in the fluorescent microscopy experiments using brain tissue sections. These derivatives are therefore superior ligands for further development.

\section{Conclusions}

We have shown that the benzothiazole-triazole and the benzothiadiazole-triazole scaffolds constitute new promising classes of ligands for amyloid- $\beta$ detection. The ligands show a significant reduction of the emission (approx. 20\%) in the presence of recombinant $A \beta_{1-42}$ amyloid fibrils in solution, an effect that likely originates from self-quenching of the ligands upon interaction with the protein fibrils. Histology staining of $\mathrm{A} \beta$-plaques in mouse brain sections demonstrates specific binding to amyloid deposits for all three ligands, which were verified by co-labeling with an anti-A $\beta$ antibody (6E10). Even though the present ligands are not superior in comparison to ThT for sensitive fluorescence detection of protein aggregates, we foresee that the synthetic pathway (azide-alkyne cycloaddition) described herein, will offer an avenue to design a variety of structurally diverse ligands that exhibit specific binding to different protein aggregates. Suggestively, the approach also enables the introduction of substituents that includes radioactive isotopes (e.g. $\left.\left[{ }^{18} \mathrm{~F}\right]\right)$ for PET or SPECT imaging. Our intention is to further investigate a library of benzothiadiazole ligands, formed via click chemistry, to generate amyloid binding agents and that can distinguish between different protein aggregates in solution and in amyloid containing brain tissue.

\section{Experimental}

\subsection{Chemistry}

All reagents and solvents were of analysis or synthesis grade and were used without further purification unless otherwise indicated. ${ }^{1} \mathrm{H}$ and ${ }^{13} \mathrm{C}$ NMR were recorded on a Bruker AVANCE III $400 \mathrm{MHz} \mathrm{NMR}$ (at 400 and $100 \mathrm{MHz}$, respectively) or on a Varian 300 instrument (Varian Inc., Santa Clara, CA, USA) (at 300 and $75 \mathrm{MHz}$, respectively) in $\mathrm{CDCl}_{3}$ or DMSO- $d_{6}$. Chemical shift is reported in ppm with the solvent residual peak as reference; $\mathrm{CDCl}_{3}\left(\delta_{\mathrm{H}} 7.26, \delta_{\mathrm{C}} 77.0\right)$, DMSO- $d_{6}\left(\delta_{\mathrm{H}} 2.50, \delta_{\mathrm{C}} 39.5\right)$ and $\mathrm{CD}_{3} \mathrm{OD}\left(\delta_{\mathrm{H}} 4.87, \delta_{\mathrm{C}} 49.0\right)$. The reactions were monitored by thin-layer chromatography (TLC), on silica plated (Silica gel $60 \mathrm{~F}_{254}$, E. Merck) aluminium sheets, detecting spots by UV (254 and $365 \mathrm{~nm}$ ). Flash chromatography was performed using Merck Silica Gel $60(40-63 \mu \mathrm{m})$. Mass spectra were obtained with the positive ion mode electrospray ionization $[\mathrm{ESI}(+)]$ source on an Agilent 6210 time of-flight liquid chromatography/mass spectrometry (MS) system. High-resolution mass data (ES-ToF) were obtained from the Division of Mass spectrometry, Department of Chemistry, Imperial College London.

4.1.1. 2-Iodo-5-methoxybenzo[ $d]$ thiazole $(2)^{\mathbf{2 4}}$. The reaction was carried out under nitrogen atmosphere in order to have an evacuation line for the $\mathrm{N}_{2}$ gas that is formed during the reaction. A solution of $\mathrm{NaNO}_{2}(0.153 \mathrm{~g}, 2.22 \mathrm{mmol})$ and KI $(0.461 \mathrm{~g}, 2.77 \mathrm{mmol})$ in $\mathrm{H}_{2} \mathrm{O}(0.7 \mathrm{~mL})$ was added dropwise to an ice-cooled suspension of 2-amino-6-methoxy-benzothiazole (1) (0.2 g, $1.11 \mathrm{mmol})$ and $p$-toluenesulfonic acid monohydrate $(0.633 \mathrm{~g}, 3.33 \mathrm{mmol})$ in acetonitrile $(5.5 \mathrm{~mL})$. The reaction was allowed to reach room temperature and was stirred overnight. The reaction mixture was quenched with $\mathrm{H}_{2} \mathrm{O}(20 \mathrm{~mL})$, basified with $2 \mathrm{M} \mathrm{NaHCO}_{3}$ (aq.) until $\mathrm{pH}$ reached 8-9, follow by the addition of $\mathrm{Na}_{2} \mathrm{~S}_{2} \mathrm{O}_{3}$ (aq.) $(2.5 \mathrm{~mL})$ to give a yellow/brown precipitate. The precipitate was filtered of and dried in vacuo to give compound 2 as a brown/gold power (0.245 g, 76\%). ${ }^{1} \mathrm{H}$ NMR (400 MHz, $\left.\mathrm{CDCl}_{3}\right) \delta 3.86(\mathrm{~s}, 3 \mathrm{H}), 7.03$ (dd, $J=2.6,9.0$ $\mathrm{Hz}, 1 \mathrm{H}), 7.28$ (d, $J=2.6 \mathrm{~Hz}, 1 \mathrm{H}), 7.90(\mathrm{~d}, J=9.0 \mathrm{~Hz}, 1 \mathrm{H}) ;{ }^{13} \mathrm{C}$ NMR $\left(100 \mathrm{MHz}, \mathrm{CDCl}_{3}\right) \delta 55.8,101.5,103.0,115.6,123.0,149.4$, 149.0, 158.0. $\operatorname{ESI}(+)-\mathrm{MS}(\mathrm{m} / \mathrm{z}):[\mathrm{M}+\mathrm{H}]^{+}$calcd for $\mathrm{C}_{8} \mathrm{H}_{7} \mathrm{INOS}$, 291.9288. Found, 291.9318.

4.1.2. 6-Methoxy-2-((trimethylsilyl)ethynyl)benzo[d]thiazole $(3)^{25,26}$. The reaction was carried out under inert conditions $\left(\mathrm{N}_{2}\right)$. Ethynyltrimethylsilane $(0.49 \mathrm{~mL}, 3.44 \mathrm{mmol})$ was added to a suspension of compound 2 (0.5 g, $1.72 \mathrm{mmol}), \mathrm{PdCl}_{2}\left(\mathrm{PPh}_{3}\right)_{2}$ (0.024 g, $0.03 \mathrm{mmol})$, and $\mathrm{CuI}(6.5 \mathrm{mg}, 0.03 \mathrm{mmol})$ in dry dichloromethane $(2.5 \mathrm{~mL})$. The reaction was refluxed for 3 hours and was then allowed to reach room temperature. The mixture was filtered through a layer of Celite and concentrated under reduced pressure. The crude product was purified by column chromatography (10\% EtOAc in hexanes) to give compound 3 as a light yellow powder $(0.312 \mathrm{~g}, 69 \%)$. The product was used in 
the next reaction step immediately or stored in the freezer for a limited time due to stability issues. ${ }^{1} \mathrm{H}$ NMR (400 $\mathrm{MHz}, \mathrm{CDCl}_{3}$ ) $\delta 0.30(\mathrm{~s}, 9 \mathrm{H}), 3.88(\mathrm{~s}, 3 \mathrm{H}), 7.11(\mathrm{dd}, J=2.5,9.1 \mathrm{~Hz}, 1 \mathrm{H}), 7.28$ $(\mathrm{d}, J=2.5 \mathrm{~Hz}, 1 \mathrm{H}), 7.92(\mathrm{~d}, J=9.0 \mathrm{~Hz}, 1 \mathrm{H}) ;{ }^{13} \mathrm{C} \mathrm{NMR}(100 \mathrm{MHz}$, $\left.\mathrm{CDCl}_{3}\right) \delta$ 0.5, 55.8, 96.9, 102.2, 103.3, 116.5, 124.2, 136.7, 145.6, 147.2, 158.8. $\mathrm{ESI}(+)-\mathrm{MS} m / z:[\mathrm{M}+\mathrm{H}]^{+}$calcd for $\mathrm{C}_{13} \mathrm{H}_{16} \mathrm{NOSSi}$, 262.0716. Found 262.0738 .

4.1.3. 3-(4-(5-Methoxybenzo[d] thiazol-2-yl)-1H-1,2,3-triazol1-yl)propan-1-ol (L1) ${ }^{25,26}$. TBAF (1 M in THF, $4.56 \mathrm{~mL}$ ) was added dropwise to a stirred solution of $3(0.298 \mathrm{~g}, 1.14 \mathrm{mmol})$ in THF (10 mL). Subsequently, 3-azidopropan-1-ol (0.231 g, $2.28 \mathrm{mmol})$ was added and then a solution of $\mathrm{CuSO}_{4} \cdot \mathrm{H}_{2} \mathrm{O}(0.114 \mathrm{~g}, 0.456 \mathrm{mmol})$ and L-sodium ascorbate $(0.090 \mathrm{~g}, 0.456 \mathrm{mmol})$ in $\mathrm{H}_{2} \mathrm{O}(10 \mathrm{~mL})$. The reaction mixture was stirred at room temperature for 3 days and then Chelex resin (approx. a small spoon) was added to remove the $\mathrm{Cu}$ catalyst. The solution was filtered after $30 \mathrm{~min}$, to remove the Chelex resin, and was then concentrated under reduced pressure. The crude residue was purified by column chromatography (100\% EtOAc) to give the product (L1) as an off white powder $(0.182 \mathrm{~g}, 55 \%) . M_{\mathrm{p}}$ 161-162 ${ }^{\circ} \mathrm{C} .{ }^{1} \mathrm{H}$ NMR (400 MHz, DMSO- $d_{6}$ ) $\delta 2.00-2.09, \mathrm{~m}, 2 \mathrm{H}$ ), 3.44 (dd, $J=6.0$, $11.1 \mathrm{~Hz}, 2 \mathrm{H}), 3.85(\mathrm{~s}, 3 \mathrm{H}), 4.53(\mathrm{t}, J=7.1 \mathrm{~Hz}, 2 \mathrm{H}), 4.71(\mathrm{t}, J=5.0$ $\mathrm{Hz}, 1 \mathrm{H}), 7.13(\mathrm{dd}, J=2.5,8.9 \mathrm{~Hz}, 1 \mathrm{H}), 7.73(\mathrm{~d}, J=2.5 \mathrm{~Hz}, 1 \mathrm{H}), 7.90$ $(\mathrm{d}, J=8.9 \mathrm{~Hz}, 1 \mathrm{H}), 8.85(\mathrm{~s}, 1 \mathrm{H}) ;{ }^{13} \mathrm{C}$ NMR (100 MHz, DMSO- $\left.d_{6}\right)$ $\delta$ 32.6, 47.3, 55.7, 57.4, 104.9, 115.9, 123.1, 223.4, 135.3, 141.9, 147.6, 156.5, 157.5. HRMS (ES-ToF) $[\mathrm{M}+\mathrm{H}]^{+}$calcd for $\mathrm{C}_{13} \mathrm{H}_{15} \mathrm{~N}_{4} \mathrm{O}_{2} \mathrm{~S}$, 291.0916. Found, 291.0924.

4.1.4. 3-(4-(Benzo[c] $][1,2,5]$ thiadiazol-4-yl)-1H-1,2,3-triazol-1yl)propan-1-ol (L2) ${ }^{30}$. The reaction was performed under inert conditions $\left(\mathrm{N}_{2}\right)$. Ethynyltrimethylsilane $(0.28 \mathrm{~mL}, 1.95 \mathrm{mmol})$ was added to a stirred solution of 4 (0.3 g, $1.39 \mathrm{mmol}), \mathrm{PPh}_{3}$ (0.038 g, $0.14 \mathrm{mmol})$, CuI (0.037 g, $0.195 \mathrm{mmol})$ and $\mathrm{PdCl}_{2}\left(\mathrm{PPh}_{3}\right)_{2}$ $(6.0 \mathrm{mg}, 0.008 \mathrm{mmol})$ in $\mathrm{NEt}_{3}(3 \mathrm{~mL})$. The mixture was heated at $90{ }^{\circ} \mathrm{C}$ for 18 hours and was then allowed to reach room temperature. The reaction mixture was diluted with dichloromethane $(10 \mathrm{~mL})$ and was then quickly filtered through a small silica column. The filtrate was concentrated under reduced pressure to give a crude solid that was used immediately in the next reaction step due to stability issues. TBAF ( $1 \mathrm{M}$ in THF, $2.79 \mathrm{~mL}$ ) was added dropwise to a stirred solution of the crude material in THF (10 mL). Subsequently, 3-azidopropan-1-ol $(0.282 \mathrm{~g}, 2.79 \mathrm{mmol})$ was added followed by the addition of a solution of $\mathrm{CuSO}_{4} \cdot \mathrm{H}_{2} \mathrm{O}(0.139 \mathrm{~g}, 0.56 \mathrm{mmol})$ and L-sodium ascorbate $(0.111 \mathrm{~g}, 0.56 \mathrm{mmol})$ in $\mathrm{H}_{2} \mathrm{O}(10 \mathrm{~mL})$. The reaction mixture was stirred at room temperature for 3 days and then Chelex resin (approx. a small spoon) was added to remove the $\mathrm{Cu}$ catalyst. The solution was stirred for $30 \mathrm{~min}$ and was then filtered in order remove the Chelex resin. The filtrate was concentrated under reduced pressure and the crude residue was purified by column chromatography (100\% EtOAc) to give L2 as yellow powder $(0.110 \mathrm{~g}, 30 \%) . M_{\mathrm{p}} 114-115{ }^{\circ} \mathrm{C}{ }^{1} \mathrm{H}$ NMR (400 MHz, $\left.\mathrm{CD}_{3} \mathrm{OD}\right) \delta 2.21$ (ddd, $J=6.1,7.0,13.1 \mathrm{~Hz}, 2 \mathrm{H}$ ), 3.65 $(\mathrm{t}, J=6.1 \mathrm{~Hz}, 2 \mathrm{H}), 4.66(\mathrm{t}, J=7.0 \mathrm{~Hz}, 2 \mathrm{H}), 7.76(\mathrm{dd}, J=7.1,8.8 \mathrm{~Hz}$, $1 \mathrm{H}), 8.00(\mathrm{dd}, J=1.0,8.8 \mathrm{~Hz}, 1 \mathrm{H}), 8.38(\mathrm{dd}, J=1.0,7.1 \mathrm{~Hz}, 1 \mathrm{H})$, $8,89(\mathrm{~s}, 1 \mathrm{H})$. The $\mathrm{OH}$-signal was not observed in the spectrum, due to solvent exchange. ${ }^{13} \mathrm{C}$ NMR $\left(100 \mathrm{MHz}, \mathrm{CD}_{3} \mathrm{OD}\right) \delta 34.1$,
48.5, 59.3, 121.9, 124.6, 126.2, 126.3, 131.0, 143.9, 153.0, 156.6. HRMS (ES-ToF) $[\mathrm{M}+\mathrm{H}]^{+}$calcd for $\mathrm{C}_{11} \mathrm{H}_{12} \mathrm{~N}_{5} \mathrm{OS}, 262.0763$. Found, 262.0772.

4.1.5. $3,3^{\prime}$-(Benzo[c] $][1,2,5]$ thiadiazole-4,7-diylbis(1H-1,2,3triazole-4,1-diyl))bis(propan-1-ol) $(\mathbf{L 3})^{30}$. The reaction was performed under inert conditions $\left(\mathrm{N}_{2}\right)$. Ethynyltrimethylsilane $(0.4 \mathrm{~mL}, 2.86 \mathrm{mmol})$ was added to a stirred solution of 5 (0.3 g, $1.02 \mathrm{mmol}), \mathrm{PPh}_{3}(0.027 \mathrm{~g}, 0.1 \mathrm{mmol}), \mathrm{CuI}(0.027 \mathrm{~g}$, $0.143 \mathrm{mmol})$ and $\mathrm{PdCl}_{2}\left(\mathrm{PPh}_{3}\right)_{2}(4.3 \mathrm{mg}, 0.006 \mathrm{mmol})$ in $\mathrm{NEt}_{3}$ $(5 \mathrm{~mL})$. The mixture was heated at $90{ }^{\circ} \mathrm{C}$ for 4 hours and was then allowed to reach room temperature. The reaction mixture was diluted with dichloromethane $(10 \mathrm{~mL})$ and was then quickly filtered through a small silica column. The filtrate was concentrated under reduced pressure to give a crude solid that was used immediately in the next reaction step due to stability issues. TBAF ( $1 \mathrm{M}$ in THF, $4.08 \mathrm{~mL}$ ) was added dropwise to a stirred solution of the crude material in THF $(10 \mathrm{~mL})$. Subsequently, 3-azidopropan1-ol $(0.248 \mathrm{~g}, 2.45 \mathrm{mmol})$ was added followed by the addition of a solution of $\mathrm{CuSO}_{4} \cdot \mathrm{H}_{2} \mathrm{O}(0.051 \mathrm{~g}, 0.20 \mathrm{mmol})$ and L-sodium ascorbate $(0.040 \mathrm{~g}, 0.2 \mathrm{mmol})$ in $\mathrm{H}_{2} \mathrm{O}(10 \mathrm{~mL})$. The reaction mixture was stirred at room temperature for 3 days and then Chelex resin (approx. a small spoon) was added to remove the $\mathrm{Cu}$ catalyst. The solution was stirred for $30 \mathrm{~min}$ and was then filtered in order remove the Chelex resin. The filtrate was concentrated under reduced pressure and the crude residue was purified by column chromatography (100\% EtOAc $\rightarrow 10 \%$ EtOH in EtOAc) to give the $\mathbf{L 3}$ as yellow powder $(0.274 \mathrm{~g}, 69 \%) . M_{\mathrm{p}} 170-171{ }^{\circ} \mathrm{C}$; ${ }^{1} \mathrm{H}$ NMR (400 MHz, CD $\left.3 \mathrm{OD}\right) \delta 2.18(\mathrm{~m}, 4 \mathrm{H}), 3.66(\mathrm{t}, J=6.1 \mathrm{~Hz}, 4 \mathrm{H})$, $4.67(\mathrm{t}, J=7.0 \mathrm{~Hz}, 4 \mathrm{H}), 8.49(\mathrm{~s}, 2 \mathrm{H}), 9.01(\mathrm{~s}, 2 \mathrm{H}) ;{ }^{13} \mathrm{C} \mathrm{NMR}$ $\left(100 \mathrm{MHz}, \mathrm{DMSO}-d_{6}\right) \delta 33.0,46.9,57.4,122.3,124.7,125.3$, 141.7, 151.5. HRMS (ES-ToF) $[\mathrm{M}+\mathrm{H}]^{+}$calcd for $\mathrm{C}_{16} \mathrm{H}_{19} \mathrm{~N}_{8} \mathrm{O}_{2} \mathrm{~S}$, 387.1352. Found, 387.1338.

\subsection{Photophysical measurements}

4.2.1. Photophysical characterization of compounds L1-L3. All photophysical measurements were performed in $5 \%$ DMSO in $0.1 \mathrm{M}$ PBS buffer ( $\mathrm{pH}$ 7.4) using $1 \mathrm{~cm}$ path length quartz cuvettes. Absorption spectra were collected using a Varian CARY 5000 UV-visible-near IR spectrophotometer or a Hitachi U-1900 spectrophotometer. The emission data were collected using a Photon Technology International 814 photomultiplier detection system or a Horiba Jobin-Yvon Fluoromax-4 instrument, and the signals were collected at $90^{\circ}$ to the incident excitation beam. The final concentrations of ligands were approximately $100 \mu \mathrm{M}$ and $100 \mathrm{nM}$ for the absorption and emission measurements, respectively (ESI, $\uparrow$ Fig. S1). Extinction coefficients were determined from samples of known concentrations. Quantum yields (QY) were measured relative to quinine sulfate $(\mathrm{QY}=0.577)^{40}$ in aqueous $\mathrm{H}_{2} \mathrm{SO}_{4}(0.1 \mathrm{M})$. The refraction index for the solvent mixture $\left(5 \% \mathrm{DMSO} / \mathrm{H}_{2} \mathrm{O}\right)$ was included in the calculations $(\eta=1.3390) .{ }^{41}$ The concentrationabsorbance relationship and the absorbance-integrated fluorescence intensity relationship were measured at known concentrations $(20,40,60,80,100$ and $250 \mu \mathrm{M})$ using a Tecan Saphire 2 micro plate reader (Tecan Group Ltd, Männerdorf, Switzerland). All the measurements were repeated in triplicates with an excitation wavelength of 310, 350 and $370 \mathrm{~nm}$ for $\mathbf{L 1}, \mathbf{L 2}$ and $\mathbf{L 3}$, respectively. 
4.2.2. Photophysical characterization of the benzothiazoletriazole (L1) and benzothiadiazole-triazole derivatives (L2 and L3) towards recombinant $A \beta_{1-42}$ amyloid fibrils. Recombinant $A \beta_{1-42}$ amyloid fibrils were prepared as previously reported in the literature; recombinant $\mathrm{A} \beta_{1-42}$ peptide lyophilized in hydroxyfluoroisopropanol (rPeptide, Athens, GA, USA) was dissolved in aqueous $\mathrm{NaOH}(2 \mathrm{mM})$ to a stock concentration of $1 \mathrm{mg} \mathrm{mL}{ }^{-1}$. The alkaline solution of $A \beta_{1-42}$ was further diluted with phosphate buffered saline (PBS, $10 \mathrm{mM}$ phosphate, $140 \mathrm{mM} \mathrm{NaCl}, 2.7 \mathrm{mM} \mathrm{KCl}, \mathrm{pH}$ 7.4) (Medicago, Sweden) to a final concentration of $10 \mu \mathrm{M}$ and added to the wells of a microtiter plate (Corning). The microtiter plate was incubated at $37{ }^{\circ} \mathrm{C}$ in quiescent mode for 48 hours and the presence of recombinant $\mathrm{A} \beta_{1-42}$ amyloid fibrils was confirmed by thioflavin T (ThT) staining. Stock solutions of L1, L2 and L3 (1 $\mathrm{mM}$ in DMSO) was added to phosphate buffered saline (PBS, $10 \mathrm{mM}$ phosphate, $140 \mathrm{mM} \mathrm{NaCl}, 2.7 \mathrm{mM} \mathrm{KCl}, \mathrm{pH}$ 7.4) or to the $10 \mu \mathrm{M}$ solution of $\mathrm{A} \beta_{1-42}$ fibrils in phosphate buffered saline (PBS, $10 \mathrm{mM}$ phosphate, $140 \mathrm{mM} \mathrm{NaCl,} 2.7 \mathrm{mM} \mathrm{KCl}, \mathrm{pH} 7.4$ ), respectively, in a 96-well plate to give a final probe concentration of $50 \mu \mathrm{M}$ ( $5 \%$ DMSO in phosphate buffered saline, PBS, $10 \mathrm{mM}$ phosphate, $140 \mathrm{mM} \mathrm{NaCl}, 2.7 \mathrm{mM} \mathrm{KCl}, \mathrm{pH} 7.4)$. Emission spectra were collected using a Tecan Saphire 2 micro plate reader (Tecan Group Ltd, Männerdorf, Switzerland). All measurements were repeated in triplicates and the excitation wavelengths used for L1, L2 and L3 were 310, 365 and $400 \mathrm{~nm}$, respectively.

\subsection{Staining of $\mathbf{A \beta}$ plaques in mouse brain sections}

This study did not directly involve experiments or handling of live animals. The brain tissue sections with $\mathrm{AD}$ pathology were provided by Prof. Frank Heppner, Department of Neuropathology, Charité - Universitätsmedizin Berlin, Germany. Animal handling to provide the histology samples used herein was carried out in accordance with relevant ethical guidelines of breeding and keeping transgenic animals as well as culling and collection of tissue for ex vivo experiments (approved by the Swiss cantonary veterinary office or the regional offices for health and social services in Berlin). $10 \mu \mathrm{m}$ cryosections of a 531 days old APP/PS1 mouse ${ }^{38}$ were placed on superfrost ultraplus glass slides. The sections were fixed in $99 \%$ ethanol for 10 minutes and rehydrated with increasing proportion of $\mathrm{dH}_{2} \mathrm{O}$ followed by equilibration in PBS pH 7.4 (Medicago, Sweden) for 10 minutes. Monoclonal anti-A $\beta$ antibody 6E10 was diluted 1:200 in PBS, administered to the sections and left at $4{ }^{\circ} \mathrm{C}$ overnight followed by extensive washing with PBS. Goat-antimouse secondary antibody with fluorescence detection maximum at $647 \mathrm{~nm}$ (GAM650, Dako, Denmark) was diluted 1:500 and incubated on the sections for 30 minutes followed by washing with PBS. The ligands were diluted from $5 \mathrm{mM}$ stocks in DMSO to $10 \mu \mathrm{M}$ working solution in PBS immediately prior to use. The ligand working solutions were applied to the sections and left at room temperature for 30 minutes followed by destaining by dipping in PBS for 10 minutes. The glass slides were left to dry in ambient air and finally mounted with Dako fluorescence mounting medium and a cover slip. Images were collected using an inverted Zeiss LSM 780 confocal microscope (Carl Zeiss, Oberkochen, Germany) with excitation wavelength at $405 \mathrm{~nm}(\mathbf{L 1}-\mathbf{L 3})$ and $680 \mathrm{~nm}$ (anti$\mathrm{A} \beta$ antibody 6E10).

\section{Acknowledgements}

This work was supported by an International postdoctoral grant from the Swedish Research Council, Dnr: 350-2012-239 (to C. D.), The Swedish Alzheimer's Foundation (to S. N.), Ciência sem Fronteiras (Conselho Nacional de Desenvolvimento Científico e Tecnológico (CNPq, Brazil, Proc. No. 245405/2012-7) and Fundação CAPES (Bolsista CAPES, Projeto PVE 118/2013) (to R. P. V.), and a Michael Smith Foundation for Health Research career Investigator Award (to T. S.). The authors also thank Alexander Sandberg and Leif B. G. Johansson for providing the amyloid-like fibrils, generated from recombinant $A \beta_{1-42}$. The brain tissue sections with AD like pathology was provided by Prof. Frank Heppner, Department of Neuropathology, Charité Universitätsmedizin Berlin, Germany.

\section{Notes and references}

1 D. J. Selkoe, Physiol. Rev., 2001, 81, 741.

2 V. H. Finder, J. Alzheimer's Dis., 2010, 22, 5.

3 K. J. Barnham, C. L. Masters and A. I. Bush, Nat. Rev. Drug Discovery, 2004, 3, 205.

4 A. S. DeToma, S. Salamekh, A. Ramamoorthy and M. H. Lim, Chem. Soc. Rev., 2012, 41, 608.

5 M. Xu, W. Ren, X. Tang, Y.-H. Hu and H. Zhang, Acta Pharmacol. Sin., 2016, 37, 719.

6 M. Shimojo, M. Higuchi, T. Suhara and N. Sahara, Front. Neurosci., 2015, 9, 482.

7 K. P. Nilsson, FEBS Lett., 2009, 583, 2593.

8 P. A. Adlard, B. A. Tran, D. I. Finkelstein, P. M. Desmond, L. A. Johnston, A. I. Bush and G. F. Egan, Front. Neurosci., $2014,8,327$.

9 H. Naiki, K. Higuchi, M. Hosokawa and T. Takeda, Anal. Biochem., 1989, 177, 244.

10 H. LeVine, 3rd, Protein Sci., 1993, 2, 404.

11 E. S. Voropai, M. P. Samtsov, K. N. Kaplevskii, A. A. Maskevich, V. I. Stepuro, O. I. Povarova, I. M. Kuznetsova, K. K. Turoverov, A. L. Fink and V. N. Uverskii, J. Appl. Spectrosc., 2003, 70, 868.

12 A. A. Reinke, G. A. Abulwerdi and J. E. Gestwicki, ChemBioChem, 2010, 11, 1889.

13 M. R. Nilsson, Methods, 2004, 34, 151.

14 H. Bennhold, Muench. Med. Wochenschr., 1922, 69, 1537.

15 P. Divry, J. Neurol. Psychiatry, 1927, 27, 643.

16 P. Frid, S. V. Anisimov and N. Popovic, Brain Res. Rev., 2007, 53, 135.

17 G. T. Westermark, K. H. Johnson and P. Westermark, Methods Enzymol., 1999, 309, 3.

18 L. Zhu, K. Ploessl and H. F. Kung, Chem. Soc. Rev., 2014, 43, 6683.

19 W. E. Klunk, H. Engler, A. Nordberg, Y. Wang, G. Blomqvist, D. P. Holt, M. Bergström, I. Savitcheva, G.-F. Huang, S. Estrada, B. Ausén, M. L. Debnath, J. Barletta, J. C. Price, 
J. Sandell, B. J. Lopresti, A. Wall, P. Koivisto, G. Antoni, C. A. Mathis and B. Långström, Ann. Neurol., 2004, 55, 306. 20 C. M. Clark, J. A. Schneider, B. J. Bedell, T. G. Beach, W. B. Bilker, M. A. Mintun, M. J. Pontecorvo, F. Hefti, A. P. Carpenter, M. L. Flitter, M. J. Krautkramer, H. F. Kung, R. E. Coleman, P. M. Doraiswamy, A. S. Fleisher, M. N. Sabbagh, C. H. Sadowsky, E. P. Reiman, S. P. Zehntner and D. M. Skovronsky, JAMA, 2011, 305, 275.

21 S. R. Choi, J. A. Schneider, D. A. Bennett, T. G. Beach, B. J. Bedell, S. P. Zehntner, M. J. Krautkramer, H. F. Kung, D. M. Skovronsky, F. Hefti and C. M. Clark, Alzheimer Dis. Assoc. Disord., 2012, 26, 8.

22 M. R. Jones, E. L. Service, J. R. Thompson, M. C. P. Wang, I. J. Kimsey, A. S. DeToma, A. Ramamoorthy, M. H. Lim and T. Storr, Metallomics, 2012, 4, 910.

23 M. R. Jones, C. Dyrager, M. Hoarau, K. J. Korshavn, M. H. Lim, A. Ramamoorthy and T. Storr, J. Inorg. Biochem., 2016, 158, 131.

24 E. A. Krasnokutskaya, N. I. Semenischeva, V. D. Filimonov and P. Knochel, Synthesis, 2007, 81.

25 J. Qi, M. S. Han, Y. C. Chang and C. H. Tung, Bioconjugate Chem., 2011, 22, 1758.

26 J. Qi and C. H. Tung, Bioorg. Med. Chem. Lett., 2011, 21, 320.

27 B. Wang, S. W. Tsang, W. Zhang, Y. Tao and M. S. Wong, Chem. Commun., 2011, 47, 9471.

28 B. A. Coombs, B. D. Lindner, R. M. Edkins, F. Rominger, A. Beeby, H. Uwe and F. Bunz, New J. Chem., 2012, 36, 550.

29 R. C. Lirag, H. T. Le and O. S. Miljanic, Chem. Commun., 2013, 49, 4304.
30 A. V. Moro, P. C. Ferreira, P. Migowski, F. S. Rodembusch, J. Dupont and D. S. Ludtke, Tetrahedron, 2013, 69, 201.

31 B. A. Neto, P. H. Carvalho and J. R. Correa, Acc. Chem. Res., 2015, 48, 1560.

32 A. K. Sharma, S. T. Pavlova, J. Kim, D. Finkelstein, N. J. Hawco, N. P. Rath, J. Kim and L. M. Mirica, J. Am. Chem. Soc., 2012, 134, 6625.

33 X. Zhuang, T. Ha, H. D. Kim, T. Centner, S. Labeit and S. Chu, Proc. Natl. Acad. Sci. U. S. A., 2000, 97, 14241.

34 D. C. Harris, Quantitative Chemical Analysis, W. H. Freeman, 2010.

35 J. R. Lakowicz, Principles of Fluorescence Spectroscopy. Springer, US, 2007.

36 S. M. Auerbach, K. A. Carrado and P. K. Dutta, Handbook of Layered Materials, CRC Press, 2004.

37 J. Zhang, Y. Fu and J. R. Lakowicz, J. Phys. Chem. C, 2007, 111, 1955.

38 R. Radde, T. Bolmont, S. A. Kaeser, J. Coomaraswamy, D. Lindau, L. Stoltze, M. E. Calhoun, F. Jaggi, H. Wolburg, S. Gengler, C. Haass, B. Ghetti, C. Czech, C. Holscher, P. M. Mathews and M. Jucker, EMBO Rep., 2006, 7, 940.

39 S. Nystrom, K. M. Psonka-Antonczyk, P. G. Ellingsen, L. B. Johansson, N. Reitan, S. Handrick, S. Prokop, F. L. Heppner, B. M. Wegenast-Braun, M. Jucker, M. Lindgren, B. T. Stokke, P. Hammarstrom and K. P. Nilsson, ACS Chem. Biol., 2013, 8, 1128.

40 J. W. Eastman, Photochem. Photobiol., 1967, 6, 55.

41 A. S. L. Gouveia, L. C. Tomé and I. M. Marrucho, J. Chem. Eng. Data, 2016, 61, 83. 